Check for updates

Cite this: RSC Adv., 2019, 9, 12428

Received 14th January 2019

Accepted 8th April 2019

DOI: 10.1039/c9ra00304e

rsc.li/rsc-advances

\section{High dispersions of nano zero valent iron supported on biochar by one-step carbothermal synthesis and its application in chromate removal}

\author{
Shifeng Li, (D) *ab Tingting You, ${ }^{a}$ Yang Guo, ${ }^{a}$ Shuhua Yao, ${ }^{a}$ Shuyan Zang, ${ }^{\text {*a }}$ Min Xiao, ${ }^{c}$ \\ Zhigang Zhang ${ }^{d}$ and Yanming Shen ${ }^{d}$
}

\begin{abstract}
A one-step carbothermal synthesis and characterization of biochar-supported nanoscale zero-valent iron $(n Z V I / B C)$ was performed for the removal of hexavalent chromium (Cr(vi)) from aqueous solution. High dispersions of nanoscale zero-valent iron supported on biochar were successfully synthesized by the pyrolysis of an iron-impregnated biomass (corn stover) as the carbon and iron source under nitrogen atmosphere. The effects of the pyrolytic temperature on the Fe mineralogies formed on the biochar are discussed. In general, the effects of the treatment time, initial solution $\mathrm{pH}$, and $\mathrm{nZVI/BC}$ dosage on the $\mathrm{Cr}(\mathrm{VI})$ removal are presented. The results showed high crystallinity and purity, and $\mathrm{nZVI/BC}$ was obtained at a pyrolytic temperature of $800{ }^{\circ} \mathrm{C}$. The batch experimental results determined that the adsorption capacity of $\mathrm{Cr}(\mathrm{V})$ decreases with the increase in the initial pH value from 4.0 to 10.0. The $\mathrm{Cr}(\mathrm{V})$ adsorption kinetics data effectively followed a pseudo-second-order kinetics with a calculated rate constant of $0.0 .3396 \mathrm{~g} \mathrm{mg}^{-1} \mathrm{~min}^{-1}$. The calculated thermodynamic parameters, such as $\Delta G^{\circ}, \Delta H^{\circ}$, and $\Delta S^{\circ}$, were evaluated, and the results indicated that the $\mathrm{Cr}(\mathrm{VI})$ reduction on $\mathrm{nZVI/BC}$ was a spontaneous and endothermic process. The adsorption mechanism of $\mathrm{Cr}(\mathrm{VI})$ was investigated by XRD and XPS analyses and the results demonstrated that $\mathrm{Cr}(\mathrm{VI})$ was reduced to $\mathrm{Cr}(\mathrm{III})$ and the oxidation of $\mathrm{nZVI}$ occurred during the reaction process. These results prove that $\mathrm{nZVI/BC}$ synthesized by a one-step carbothermal method can be considered as a potential candidate for the removal of $\mathrm{Cr}(\mathrm{VI})$ from aqueous solutions.
\end{abstract}

\section{Introduction}

Chromium (Cr), one of the most abundant contaminants found in the environment, especially in water and soil, is mainly a byproduct of electroplating, ore mining, leather tanning, pigment making etc. ${ }^{1}$ In natural aquatic environments, $\mathrm{Cr}(\mathrm{vI})$ and $\mathrm{Cr}(\mathrm{III})$ are the predominant forms of chromium. In general, $\mathrm{Cr}(\mathrm{III})$ occurs naturally and is an essential micronutrient for humans. However, $\mathrm{Cr}(\mathrm{vI})$ is regarded to be toxic and potentially carcinogenic. ${ }^{2}$ Therefore, the treatment of $\mathrm{Cr}(\mathrm{vr})$-containing wastewater has become a booming research area.

Considerable research efforts have been focused on various methods of removal of $\mathrm{Cr}(\mathrm{vI})$ from $\mathrm{Cr}(\mathrm{vI})$-containing wastewater, including adsorption, ion exchange, flotation, coagulation,

${ }^{a}$ Liaoning Engineering Research Center for Treatment and Recycling of Industrially Discharged Heavy Metals, Shenyang University of Chemical Technology, Shenyang 110142, China.E-mail: li.shi.feng@163.com; zangshuyan@126.com

${ }^{b}$ Key Laboratory of Pollution Ecology and Environmental Engineering, Institute of Applied Ecology, Chinese Academy of Sciences, Shenyang 110016, China

'School of Environment, Key Laboratory of Regional Environment and EcoRemediation, Ministry of Education, Shenyang University, 110044 Shenyang, Liaoning, China

${ }^{d}$ Liaoning Provincial Key Laboratory of Chemical Separation Technology, Shenyang University of Chemical Technology, Shenyang 110142, China membrane technologies and chemical reduction. ${ }^{3-8}$ Among these technologies, the removal of $\mathrm{Cr}(\mathrm{vI})$ by nZVI, which has a large surface area and a high chemical reduction has been thought as a suitable process. ${ }^{9}$ However, there are still some limitations that need to be addressed, especially when the nZVI particles tend to agglomerate and passivate in the surface during use. ${ }^{10}$ To stabilize the as-synthesized iron nanoparticles, several materials have been investigated as supports, such as $\mathrm{SiO}_{2},{ }^{11}$ montmorillonite, ${ }^{12}$ resin, ${ }^{13}$ activated carbon ${ }^{14}$ and biochar. ${ }^{15-18}$ Among these materials, biochar is used extensively for environmental application because it can be easily obtained from many kinds of waste biomass and can be produced at relatively low-cost. ${ }^{5,16,19,20}$ Despite recent advances in the environmental applications of nZVI/BC, there remain numerous challenges that limit its practical use. ${ }^{21,22}$ It is well known that most preparation procedures using $\mathrm{nZVI} / \mathrm{BC}$ can be divided into two steps. First, biochar is prepared by combusting biomass under low oxygen conditions (pyrolysis). Then, ferric salt is loaded onto the biochar followed by reduction using borohydride to produce zero-valent iron nanoparticles on the biochar support. Therefore, such procedures are not only costly but also potentially cause secondary contamination to the environment (such as the discharge of borate-containing wastewater). ${ }^{21}$ 
One-step pyrolysis can be an alternative method for nZVI/BC or Fe-oxide/BC preparation for the applications in environmental remediation..$^{21,23-26}$ Liu et al. ${ }^{24}$ reported the synthesis of $\mathrm{nZVI} / \mathrm{C}$ composites from natural hematite and sawdust via a one-step pyrolysis method. The composite showed good potential application in the adsorption of $\mathrm{U}(\mathrm{vI})$ from aqueous solutions. Wang et al. ${ }^{26}$ prepared Fe and $\mathrm{Zn}$ oxides supported by biochar through a one-step pyrolysis at $600{ }^{\circ} \mathrm{C}$ and used it successfully for the removal of $p$-nitrophenol in wastewater. He et al. ${ }^{23}$ also prepared iron oxide supported on biochar via a onestep thermal pyrolysis $\left(600^{\circ} \mathrm{C}\right)$ of corn straw impregnated with $\mathrm{FeCl}_{3}$ solution, and then investigated the arsenate removal performance and mechanisms. Lawrinenko et al. ${ }^{21}$ found that some biomass, such as corn stover and cellulose, pre-treated with $\mathrm{FeCl}_{3}$ could effectively reduce $\mathrm{Fe}$ to $\mathrm{ZVI}$ at $900{ }^{\circ} \mathrm{C}$. Nonetheless, the structural characteristics of composites (the formation of nZVI/BC or Fe-oxides/BC) at different pyrolysis temperatures and the treatment of other heavy metals (such as $\mathrm{Cr}(\mathrm{vI}))$ still require further investigation.

In this study, a one-step carbothermal synthesis method was developed to prepare $\mathrm{nZVI/BC}$ composites at different temperatures for chromate removal. The objectives of this study were (1) to prepare nZVI/BC composites at different temperatures and to investigate the structural characteristics of the composite using XRD, $\mathrm{N}_{2}$ adsorption-desorption, TEM, and XPS; (2) to investigate the adsorption and desorption kinetics and thermodynamic behaviour of $\mathrm{Cr}(\mathrm{vI})$ on the nZVI/BC composite using the batch equilibration method; and (3) to propose the potential adsorption mechanisms for $\mathrm{Cr}(\mathrm{vI})$ by the nZVI/BC composite.

\section{Materials and methods}

\subsection{Chemicals}

All reagents were of analytical grade except hydrochloric acid (guaranteed reagent) and were used directly without further purification. Hydrochloric acid, ferric chloride hexahydrate, sulfuric acid, phosphoric acid, sodium hydroxide, potassium dichromate, and diphenylcarbazide were purchased from Sinopharm (China). $500 \mathrm{mg} \mathrm{L}^{-1} \mathrm{Cr}(\mathrm{vr})$ standard solutions were purchased from Aladdin (China). Ultrapure water (Millipore) was used in our study.

\subsection{Synthesis of $\mathrm{nZVI} / \mathrm{BC}$}

The nZVI/BC was prepared by a one-step carbothermal synthesis method by the following procedure: first, the corn stover was ground, dried naturally, and filtered through a sieve having a 100-mesh $(0.15 \mathrm{~mm})$. Then a mixture of $1 \mathrm{~g}$ corn straw powder and a solution containing $0.405 \mathrm{~g} \mathrm{FeCl}_{3} \cdot 6 \mathrm{H}_{2} \mathrm{O}$ and $40 \mathrm{~mL}$ ultrapure water was stirred for $24 \mathrm{~h}$, and dried at $80{ }^{\circ} \mathrm{C}$ for $72 \mathrm{~h}$ in an air-dry oven. Finally, the pre-treated corn straw was pyrolyzed for $2 \mathrm{~h}$ at $800{ }^{\circ} \mathrm{C}$ with a heating rate of $5{ }^{\circ} \mathrm{C} \mathrm{min}^{-1}$ in a tube furnace under $80 \mathrm{~mL} \mathrm{~min}{ }^{-1}$ nitrogen flow. The resulting $\mathrm{nZVI} / \mathrm{BC}$ was ground and passed through a sieve having 200mesh $(0.074 \mathrm{~mm})$ without further treatment.

\subsection{Characterizations}

XRD patterns of the pyrolysis products were recorded using a Bruker D8 Advance XRD diffractometer $(\mathrm{Cu} \mathrm{K} \alpha, 40 \mathrm{kV}$ and 40 $\mathrm{mA}, \lambda=1.5406 \AA$ ). The BET measurements were performed and the pore-size distribution was evaluated using a Quantachrome Autosorb 1-C adsorption instrument. The morphology of the sample surface was observed by TEM (FEI Tecnai G2 F20) and FE-SEM (S4800 HITACHI). An X-ray photoelectron spectrometer (Thermo Scientific 250Xi, Al Ka, $h \nu=1486.6 \mathrm{eV}, 15 \mathrm{kV}$ and, 10 $\mathrm{mA}$ ) was used for the determination of the chemical states of the surface $\mathrm{Cr}$ and Fe elements. The $\mathrm{Cr}(\mathrm{vI})$ concentration was detected using a UV-Vis spectrophotometer (Shimadzu UV2550). Total Fe content in nZVI/BC was analysed by an atomic absorption spectrometer (Shimadzu AA6880).

\section{$2.4 \operatorname{Cr}(\mathrm{vI})$ adsorption procedures}

2.4.1 Effect of $\mathbf{n Z V I} / \mathbf{B C}$ dosage. In this study, the addition of $\mathrm{nZVI} / \mathrm{BC}$ in the range of $0.025-2 \mathrm{~g} \mathrm{~L}^{-1}$ revealed the effect of nZVI/BC dosage on the $\mathrm{Cr}(\mathrm{vI})$ removal. The initial $\mathrm{Cr}(\mathrm{vI})$ concentration was set as $10 \mathrm{mg} \mathrm{L}^{-1}$, and the $\mathrm{pH}$ value was set to 4.0 at $25^{\circ} \mathrm{C}$.

2.4.2 Effect of $\mathbf{p H}$. A given dose of the $\mathrm{Cr}(\mathrm{vI})$ solution was added into the pre-treated nZVI/BC suspension, and the $\mathrm{pH}$ value was adjusted in advance in the range of $4.0-10.0$ by $\mathrm{NaOH}$ and $\mathrm{HCl}$. After the reaction, the suspension was centrifugally separated, and then passed through a 0.45 -micron filter. The $\mathrm{Cr}(\mathrm{vI})$ in the filtrate was diluted to the appropriate concentrations, and then analysed on a UV-Vis spectrophotometer $(\lambda=$ $540 \mathrm{~nm})$.

2.4.3 Kinetic and thermodynamic procedures. In the kinetic experiment, the nZVI/BC $\left(1.5 \mathrm{~g} \mathrm{~L}^{-1}\right)$ reacted with the $\mathrm{Cr}(\mathrm{vI})$ solution $\left(750 \mathrm{~mL}, 10 \mathrm{mg} \mathrm{L}^{-1}\right)$ at $\mathrm{pH} 4.0$ and ambient temperature. At different intervals, a solution was taken out of the suspensions, centrifugally separated, and passed through a 0.45-micron filter membrane, and then analysed using a UVVis spectrophotometer.

\subsection{Adsorption kinetics study}

The adsorption kinetics process can be described by pseudofirst-order, ${ }^{27}$ pseudo-second-order, ${ }^{28}$ Elovich, ${ }^{29}$ and intraparticle diffusion $^{30}$ models. The equation for the pseudo-first-order kinetics model is expressed as

$$
\log \left(Q_{\mathrm{e}}-Q_{\mathrm{t}}\right)=\log Q_{\mathrm{e}}-\frac{k_{1}}{2.303} t
$$

where $k_{1}\left(\mathrm{~min}^{-1}\right)$ is the pseudo-first-order rate constant, and $Q_{\mathrm{e}}$ $\left(\mathrm{mg} \mathrm{g}^{-1}\right)$ and $Q_{t}\left(\mathrm{mg} \mathrm{g}^{-1}\right)$ are the adsorption capacities of $\mathrm{Cr}(\mathrm{v})$ at equilibrium and at time $t(\mathrm{~min})$, respectively.

The pseudo-second-order rate equation can be expressed as

$$
\frac{t}{Q_{t}}=\frac{1}{k_{2} Q_{\mathrm{e}}{ }^{2}}+\frac{t}{Q_{\mathrm{e}}}
$$

where $k_{2}\left(\mathrm{~g} \mathrm{mg}^{-1} \mathrm{~min}^{-1}\right)$ is the pseudo-second-order rate constant.

The Elovich kinetics equation can be represented as 


$$
Q_{t}=a+b \ln t
$$

where $a\left(\mathrm{mg} \mathrm{g}^{-1}\right)$ and $b\left(\mathrm{mg}^{-1}\right)$ are the Elovich adsorption kinetics constants.

The intraparticle diffusion model is expressed as

$$
Q_{t}=k_{\mathrm{p}} t^{0.5}+C
$$

where $k_{\mathrm{p}}\left(\mathrm{mg} \mathrm{g}^{-1} \min ^{-0.5}\right)$ is the intraparticle diffusion rate constant.

\subsection{Adsorption isotherm study}

The Langmuir model is suitable for describing uniform adsorption processes, where each adsorption site on the surface of the sorbent is identical and the adsorption process is thought as monolayer adsorption. The Langmuir model can be expressed by the following eqn (5). ${ }^{31}$

$$
\frac{C_{\mathrm{e}}}{Q_{\mathrm{e}}}=\frac{1}{Q_{\mathrm{m}} b}+\frac{C_{\mathrm{e}}}{Q_{\mathrm{m}}}
$$

where $C_{\mathrm{e}}\left(\mathrm{mg} \mathrm{L}^{-1}\right)$ is the adsorbate equilibrium ion concentration in solution and $Q_{\mathrm{e}}\left(\mathrm{mg} \mathrm{g}^{-1}\right)$ is the equilibrium amount of adsorbed ions on the sorbent, $b\left(\mathrm{~L} \mathrm{mg}^{-1}\right)$ is the Langmuir isotherm constant related to the energy of the sorbent, and $Q_{\mathrm{m}}$ $\left(\mathrm{mg} \mathrm{g}^{-1}\right)$ is the calculated maximum adsorption capacity for a monolayer coverage. The adsorption on a heterogeneous surface can be described empirically by the Freundlich model and can be represented by the following eqn (6). ${ }^{32}$

$$
\log Q_{\mathrm{e}}=\log K_{\mathrm{F}} \frac{1}{Q_{\mathrm{m}} b}+\frac{1}{n} \log C_{\mathrm{e}}
$$

where $K_{\mathrm{F}}\left(\mathrm{L} \mathrm{mg}^{-1}\right)$ is the Freundlich affinity coefficient, and $n$ is the Freundlich constant.

\subsection{Thermodynamic study}

The information on the energy change during the treatment of the $\mathrm{Cr}(\mathrm{vI})$-containing aqueous solution by $\mathrm{nZVI} / \mathrm{BC}$ can be provided by the thermodynamic equilibrium constant $(K)$ under different temperatures. ${ }^{33,34}$ First, the standard Gibbs free energy $\Delta G^{\circ}\left(\mathrm{kJ} \mathrm{mol}^{-1}\right)$ can be obtained from the parameter $K$ (eqn (7)). Then, the standard enthalpy change $\Delta H^{\circ}\left(\mathrm{kJ} \mathrm{mol}^{-1}\right)$, and the standard entropy change $\Delta S^{\circ}\left(\mathrm{J} \mathrm{mol}^{-1} \mathrm{~K}^{-1}\right)$ were calculated from the slope and intercept of the linear plot of $\ln K v s .1 / T$, respectively, where $R$ is the universal gas constant $\left(8.314 \mathrm{~J} \mathrm{~mol}^{-1}\right.$ $\mathrm{K}^{-1}$ ), and $T$ is the solute temperature (K).

$$
\begin{aligned}
& \Delta G^{\circ}=-R T \ln K \\
& \ln K=\frac{\Delta S^{\circ}}{R}-\frac{\Delta H^{\circ}}{R T}
\end{aligned}
$$

\section{Results and discussion}

\subsection{Characterization of $\mathrm{nZVI} / \mathrm{BC}$}

As we know, the pyrolytic temperature can influence the Fe mineralogies that form in the biochar. ${ }^{21}$ As a result, a temperature in the range of $600-900{ }^{\circ} \mathrm{C}$ was set during the pyrolysis process. The X-ray diffraction spectra of the pyrolysis products are shown in Fig. 1. In Fig. 1a, the diffraction peaks at $35.3^{\circ}, 56.8^{\circ}$, and $62.3^{\circ} 2 \theta$ are attributed to the (311), (511), and (440) characteristic diffraction peaks of magnetite (JCPDS no. 19-0629), respectively, indicating that magnetite but not ZVI was formed at $600{ }^{\circ} \mathrm{C}$. As illustrated in Fig. 1(b and c), the (110), (200), and (211) characteristic diffraction peaks of the zero valent iron can be found at $44.6^{\circ}, 65.0^{\circ}$, and $82.3^{\circ}$ (JCPDS no. 060696) respectively, suggesting the presence of zero valent iron in the pyrolysis products. ${ }^{25}$ Obviously, in the pyrolysis products at $800{ }^{\circ} \mathrm{C}$ and $900{ }^{\circ} \mathrm{C}, \mathrm{Fe}$ (III) derived from ferric chloride was transformed to zero valent iron with high and sharp XRD diffraction peaks. However, the observation of no zero valent iron formation at $600{ }^{\circ} \mathrm{C}$ indicated that the pyrolysis temperature of $600{ }^{\circ} \mathrm{C}$ was not enough. The reaction equation is described as follows: $:^{25}$

$$
\begin{gathered}
2 \mathrm{FeCl}_{3} \cdot 6 \mathrm{H}_{2} \mathrm{O}=\mathrm{Fe}_{2} \mathrm{O}_{3}+6 \mathrm{HCl} \uparrow+3 \mathrm{H}_{2} \mathrm{O} \uparrow \\
2 \mathrm{Fe}_{2} \mathrm{O}_{3}+3 \mathrm{C}=4 \mathrm{Fe}+3 \mathrm{CO}_{2} \uparrow
\end{gathered}
$$

Thus, in this study the pyrolysis temperature was set as $800{ }^{\circ} \mathrm{C}$.

The $\mathrm{N}_{2}$ adsorption-desorption isotherm and the DFT pore diameter distribution of the $\mathrm{nZVI} / \mathrm{BC}$ and $\mathrm{BC}$ prepared by pyrolysis at $800{ }^{\circ} \mathrm{C}$ are illustrated in Fig. 2. The adsorptiondesorption isotherm curves of the $\mathrm{nZVI} / \mathrm{BC}$ and $\mathrm{BC}$ can be categorized as type IV, and the H3 type hysteresis loop shows the mesoporous characteristics of the nZVI/BC composite. ${ }^{35}$ Based on the isotherm of the $\mathrm{N}_{2}$ adsorption and desorption, the calculated BET surface area for the $\mathrm{nZVI} / \mathrm{BC}$ and the $\mathrm{BC}$ are $224.8 \mathrm{~m}^{2} \mathrm{~g}^{-1}$ and $339.6 \mathrm{~m}^{2} \mathrm{~g}^{-1}$, respectively. The decrease in the BET surface area for $\mathrm{nZVI} / \mathrm{BC}$ could be caused by the occupation of some of the pore space within BC. As shown in Fig. $2 \mathrm{~b}$, the most probable pore size for $\mathrm{nZVI} / \mathrm{BC}$ is located at about $1.84 \mathrm{~nm}$.

The typical FE-SEM image for BC (a) and the TEM image for nZVI/BC (b) are presented in Fig. 3. As shown in Fig. 3a, BC shows a smooth and compact surface morphology. Fig. 3b

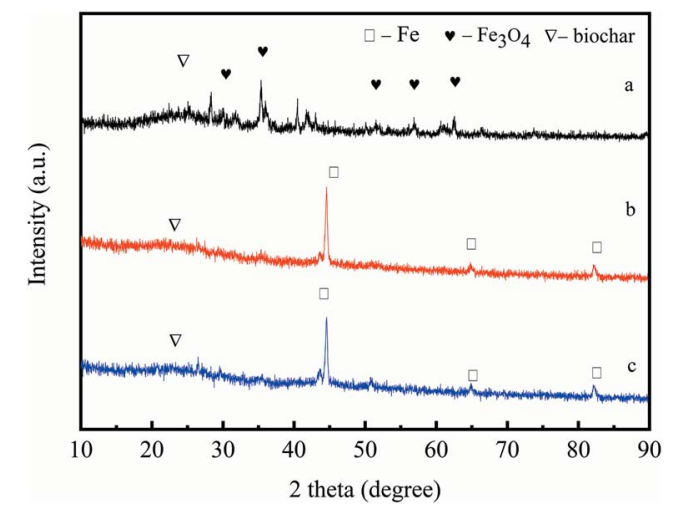

Fig. 1 XRD diffraction patterns of the $\mathrm{nZVI} / \mathrm{BC}$ (or $\mathrm{Fe}_{3} \mathrm{O}_{4} / \mathrm{BC}$ ) prepared by pyrolysis at $600^{\circ} \mathrm{C}$ (a), $800^{\circ} \mathrm{C}$ (b) and $900^{\circ} \mathrm{C}$ (c), respectively. 

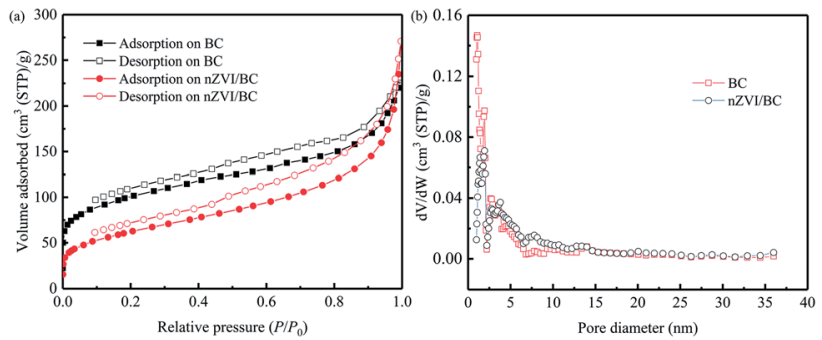

Fig. $2 \mathrm{~N}_{2}$ adsorption/desorption isotherm (a) and the DFT pore diameter distribution (b) of the $\mathrm{BC}$ and the $\mathrm{nZVI} / \mathrm{BC}$.
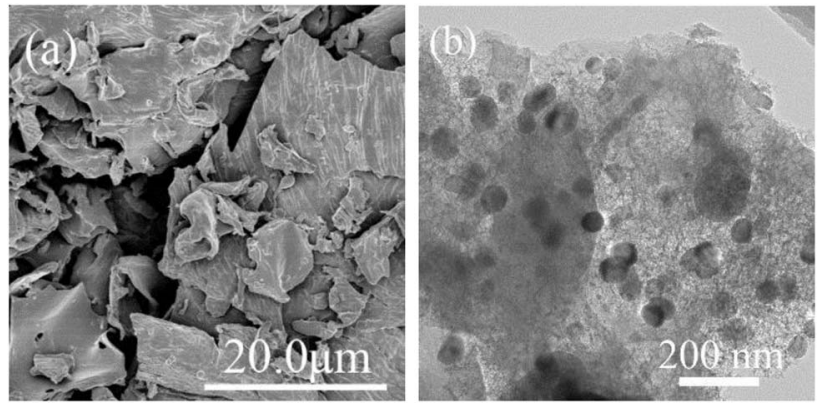

Fig. 3 Scanning electron microscopy morphology of $B C$ (a) and transmission electron microscopy image of the $n Z \mathrm{VI} / \mathrm{BC}$ (b).

indicates that the zero valent iron particles with a diameter of about $50 \mathrm{~nm}$ were well-dispersed on the biochar, demonstrating that the agglomeration of nZVI particles was successfully prevented in the presence of biochar during pyrolysis. Moreover, the total Fe content in $\mathrm{nZVI} / \mathrm{BC}$ composites as determined by AAS is $12.5 \mathrm{wt} \%$.

\section{$3.2 \mathrm{Cr}(\mathrm{vi})$ removal capacity}

Fig. 4 shows that the removal capacity of $\mathrm{Cr}(\mathrm{vI})$ varies with different nZVI/BC dosages after 240 min treatment at ambient temperature. As we can see in Fig. 4 , the removal capacity rises with the increase in the nZVI/BC dosage. For example, about

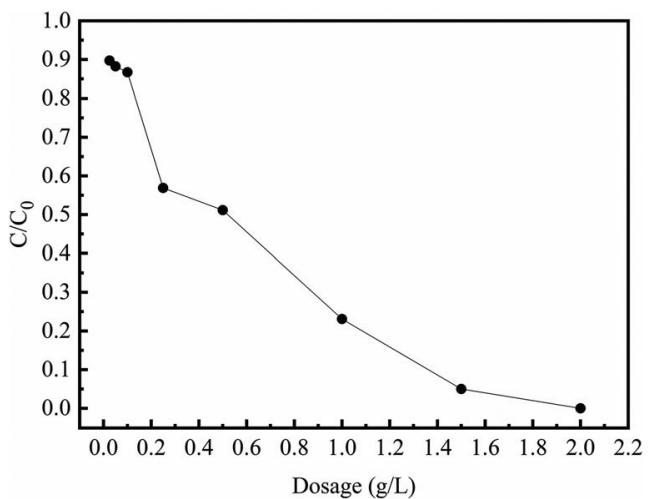

Fig. 4 The $\mathrm{Cr}(\mathrm{VI})$ removal at different $\mathrm{nZVI} / \mathrm{BC}$ dosages $\left(C_{0}: 10 \mathrm{mg} \mathrm{L}^{-1}\right.$; initial $\mathrm{pH}: 4.0 ; \mathrm{T}: 25^{\circ} \mathrm{C}$ ).

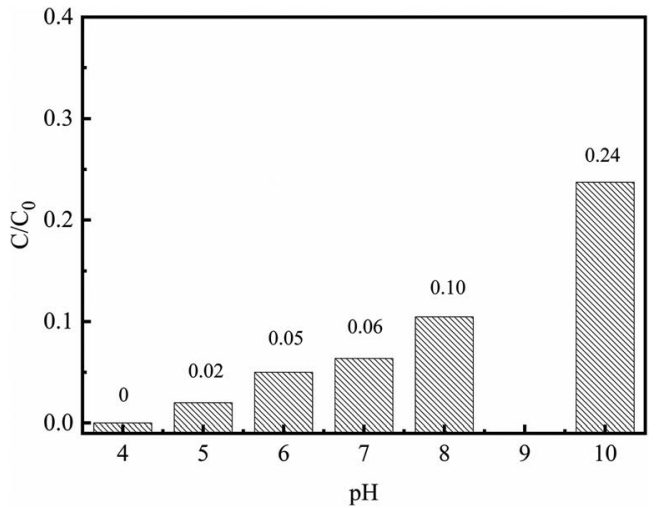

Fig. 5 The effect of the initial $\mathrm{pH}$ on $\mathrm{Cr}(\mathrm{v})$ removal $\left(C_{0}: 10 \mathrm{mg} \mathrm{L}^{-1}\right.$, nZVI/BC dosage: $1.5 \mathrm{~g} \mathrm{~L}^{-1} ; \mathrm{T:} 25^{\circ} \mathrm{C}$ ).

more than $96 \%$ of $\mathrm{Cr}(\mathrm{v})$ was removed with the $\mathrm{nZVI} / \mathrm{BC}$ dosage of $1.5 \mathrm{~g} \mathrm{~L}^{-1}$.

The effect of the initial $\mathrm{pH}$ on the removal capacity of $\mathrm{Cr}(\mathrm{vI})$ is shown in Fig. 5. It was found that the removal capacity of $\mathrm{Cr}(\mathrm{vI})$ was apparently affected by the $\mathrm{pH}$ in the range of 4.0-10.0. The $\mathrm{Cr}(\mathrm{vI})$ removal percentage declined from $100 \%$ to $76 \%$ with the solution $\mathrm{pH}$ increasing from 4 to 10 . At $\mathrm{pH} \sim 4.0, \mathrm{HCrO}_{4}{ }^{-}$is the main form of the $\mathrm{Cr}(\mathrm{vI})$, while $\mathrm{CrO}_{4}{ }^{2-}$ and $\mathrm{Cr}_{2} \mathrm{O}_{7}{ }^{2-}$ are present mainly when the $\mathrm{pH}$ value varies from 8.0 to $10.0{ }^{33}$ Therefore, at high solution $\mathrm{pH}$, the strong competition between the $\mathrm{Cr}(\mathrm{vI})$ species and the hydroxyls $\left(\mathrm{OH}^{-}\right)$should be the main reason for the low $\mathrm{Cr}(\mathrm{vI})$ removal capacity. In addition, the lower $\mathrm{pH}$ could contribute to the removal of the passive iron oxide layer, which covers the surface of nZVI and results in fresh nZVI being exposed to the surrounding $\mathrm{Cr}(\mathrm{VI})$ solution. ${ }^{33}$ Hence, the initial $\mathrm{pH}$ of the $\mathrm{Cr}(\mathrm{vI})$ solution was set as 4.0 in all subsequent procedures.

\subsection{Adsorption kinetics of $\mathrm{Cr}(\mathrm{vI})$}

Fig. 6 shows the adsorption kinetics of $\mathrm{Cr}(\mathrm{vI})$ on the nZVI/BC and BC. As can be seen from Fig. 6, in the presence of BC, the $\mathrm{Cr}(\mathrm{vI})$ concentration reduces slightly in the first $30 \mathrm{~min}$. However, with nZVI/BC as the sorbent, the $\mathrm{Cr}(\mathrm{vI})$ concentration

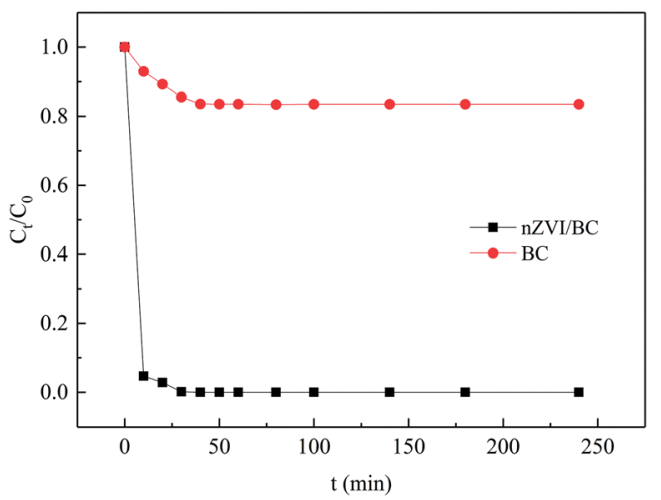

Fig. 6 The adsorption kinetics of $\mathrm{Cr}(\mathrm{VI})$ on the $\mathrm{nZVI} / \mathrm{BC}$ and $\mathrm{BC}\left(\mathrm{C}_{0}\right.$ : $10 \mathrm{mg} \mathrm{L}^{-1}$; sorbent dosage: $1.5 \mathrm{~g} \mathrm{~L}^{-1}$; $\mathrm{pH}: 4.0 ; \mathrm{T}: 25^{\circ} \mathrm{C}$ ). 

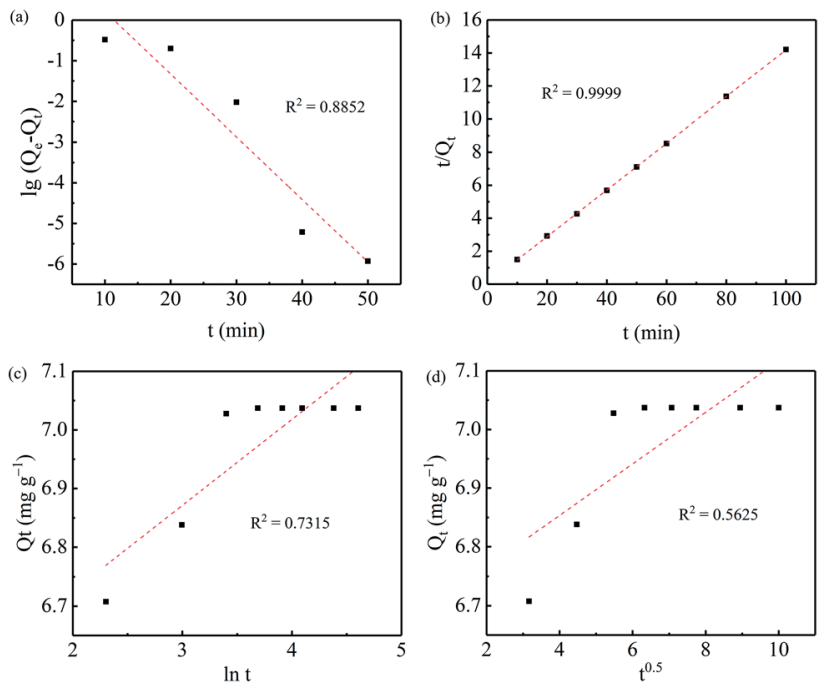

Fig. 7 The plots of the pseudo-first-order (a), pseudo-second-order (b), Elovich (c) and intraparticulate diffusion (d) models for the adsorption of $\mathrm{Cr}(\mathrm{VI})$ on the $\mathrm{nZVI} / \mathrm{BC}$.

Table 1 The adsorption kinetics parameters of $\mathrm{Cr}(\mathrm{VI})$ on the $\mathrm{nZVI} / \mathrm{BC}$

\begin{tabular}{lll}
\hline Model & Parameters & \\
\hline Pseudo-first-order & $k_{1}\left(\mathrm{~min}^{-1}\right)$ & 0.3548 \\
& $Q_{\mathrm{e}}\left(\mathrm{mg} \mathrm{g}^{-1}\right)$ & 56.51 \\
& $R^{2}$ & 0.8852 \\
Pseudo-second-order & $k_{2}\left(\mathrm{mg} \mathrm{g}^{-1} \mathrm{~min}^{-1}\right)$ & 0.3396 \\
& $Q_{\mathrm{e}}\left(\mathrm{mg} \mathrm{g}^{-1}\right)$ & 7.08 \\
Elovich & $R^{2}\left(\mathrm{mg} \mathrm{g}^{-1}\right)$ & 0.9999 \\
& $a\left(\mathrm{mg} \mathrm{g}^{-1}\right)$ & 6.43 \\
Intraparticle diffusion & $R^{2}$ & 0.15 \\
& $k_{\mathrm{p}}\left(\mathrm{mg} \mathrm{g}^{-1}\right)$ & 0.7315 \\
& $C$ & 0.043 \\
& $R^{2}$ & 6.68 \\
& & 0.5625
\end{tabular}

decreases rapidly from 10 to $0.046 \mathrm{mg} \mathrm{L}^{-1}$ in the first few minutes and then reaches equilibrium (near 0 ) after $30 \mathrm{~min}$. This result shows that the adsorption capacity of $\mathrm{Cr}(\mathrm{vI})$ on the $\mathrm{BC}$ is far below that on the $\mathrm{nZVI} / \mathrm{BC}$, which also can be deduced by the compact surface morphology and low specific surface area of BC (Fig. 2 and 3). The kinetics of the adsorption process on nZVI/BC was also fitted by different kinetics models such as the pseudo-first-order, pseudo-second-order, Elovich and intraparticle diffusion models. As shown in Fig. 7 and Table 1, the kinetics data for the $\mathrm{Cr}(\mathrm{vI})$ adsorption were better fitted into the pseudo-second-order model $\left(R^{2}=0.9999\right)$ than the other models.

Comparisons of the $\mathrm{Cr}(\mathrm{vI})$ adsorption kinetics rate constants of nZVI and other supported nZVI are summarized in Table 2. The results show that the nZVI/BC prepared by a one-step pyrolysis exhibited the highest adsorption rate for $\mathrm{Cr}(\mathrm{vI})$ than the related adsorbents reported in literature.

\subsection{Thermodynamic analysis}

In this study, we also studied the thermodynamic characteristics of the $\mathrm{Cr}(\mathrm{vI})$ removal procedures. The $\mathrm{Cr}(\mathrm{vI})$ adsorption isotherms are shown in Fig. 8 and fitted by the Langmuir and Freundlich isotherm model (Fig. 9). As shown in Fig. 9 and Table 3, the thermodynamic data for the $\mathrm{Cr}(\mathrm{vI})$ adsorption process fitted well to the Langmuir model.

The standard Gibbs free energy $\left(\Delta G^{\circ}, \mathrm{kJ} \mathrm{mol}^{-1}\right)$ for $\mathrm{Cr}(\mathrm{vI})$ adsorption on the nZVI/BC can be calculated by eqn ( 7$)$. Then, the standard enthalpy change $\left(\Delta H^{\circ}, \mathrm{kJ} \mathrm{mol}^{-1}\right)$ and standard entropy change $\left(\Delta S^{\circ}, \mathrm{J} \mathrm{mol}^{-1} \mathrm{~K}^{-1}\right)$ can be calculated according to eqn (8) by plotting ln Kversus $1 / T$ (Fig. 10). The results for the thermodynamic parameters are listed in Table 4. As shown in Table $4, \Delta H^{\circ}$ and $\Delta S^{\circ}$ are positive and the $\Delta G^{\circ}$ is negative, which indicates that the $\mathrm{Cr}(\mathrm{vI})$ adsorption on the $\mathrm{nZVI} / \mathrm{BC}$ is thermodynamically endothermic and spontaneous. The thermodynamic analysis shows that the treatment of a $\mathrm{Cr}(\mathrm{vI})$-containing aqueous solution with $\mathrm{nZVI} / \mathrm{BC}$ is spontaneous and a high temperature is more favorable. ${ }^{33,34}$

As listed in Table 5, the maximum $\mathrm{Cr}(\mathrm{vI})$ adsorption capacity for nZVI at $298 \mathrm{~K}$ was compared to other related adsorbents reported in literatures. It can be seen that the $\mathrm{Cr}(\mathrm{vI})$ adsorption capacity on the nZVI/BC synthesized via a one-step pyrolysis is often higher than most nZVI sorbents prepared by liquid reduction.

\subsection{Adsorption mechanisms of $\mathrm{Cr}(\mathrm{vI})$}

In this study, both XRD and XPS were applied to analyse the nZVI/BC after treatment with a $\mathrm{Cr}(\mathrm{vI})$ solution to reveal the mechanisms. After reacting with the $\mathrm{Cr}(\mathrm{VI})$ solution for $2 \mathrm{~h}$, the XRD patterns of the nZVI/BC was not significantly changed (Fig. 11). However, compared to the freshly prepared nZVI/BC, iron oxide crystalline phases were distinctly detected. As shown in Fig. $11 \mathrm{~b}$, the diffraction peaks at $28.2^{\circ}, 35.5^{\circ}$, and $62.5^{\circ}$, could be attributed to the characteristic diffraction peaks

Table 2 Comparison of $\mathrm{Cr}(\mathrm{VI})$ adsorption kinetics rate constant of the $\mathrm{nZVI}$ related adsorbents ${ }^{a}$

\begin{tabular}{|c|c|c|c|c|}
\hline $\mathrm{nZVI} / \mathrm{AC}^{\mathrm{a}}$ & 10 & 5.0 & 0.0150 & 36 \\
\hline $\mathrm{nZVI} / \mathrm{BC}^{\mathrm{a}}$ & 10 & - & 0.1905 & 17 \\
\hline $\mathrm{nZVI} / \mathrm{BC}^{\mathrm{b}}$ & 10 & 4.0 & 0.3396 & This study \\
\hline
\end{tabular}

${ }^{a}$ nZVI synthesis method: a, liquid reduction; $\mathrm{b}$, one-step pyrolysis. 


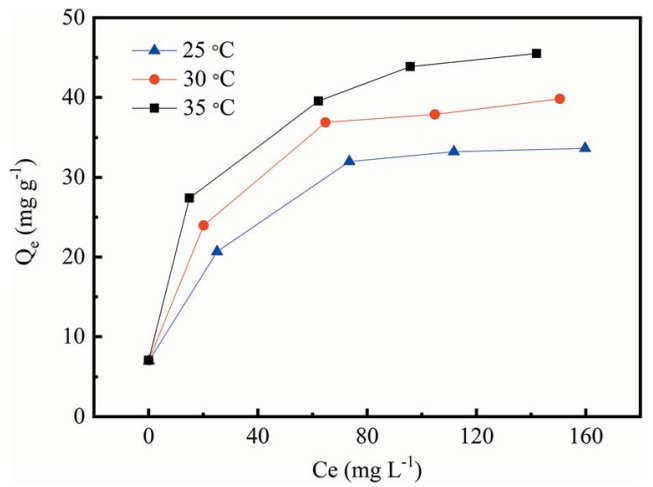

Fig. $8 \mathrm{Cr}(\mathrm{VI})$ adsorption isotherms on the $\mathrm{nZVI/BC}$ (nZVI/BC dosage: $1.5 \mathrm{~g} \mathrm{~L}^{-1} ; \mathrm{pH}: 4.0 ; \mathrm{T}: 25,30$ and $35^{\circ} \mathrm{C}$ ).
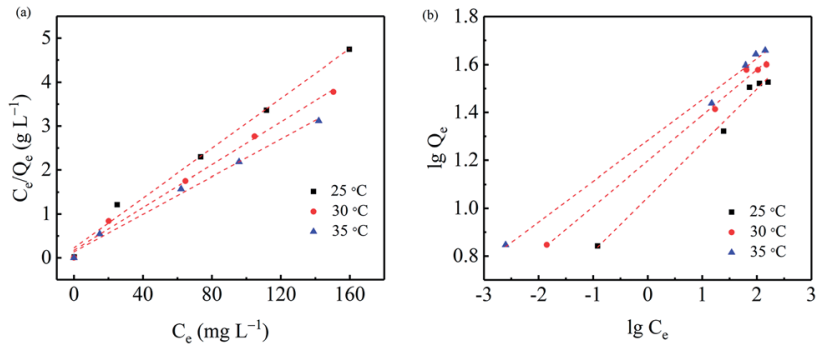

Fig. 9 Plots of the Langmuir isotherm model (a) and the Freundlich isotherm model (b) for the removal of $\mathrm{Cr}(\mathrm{VI})$ ions with $\mathrm{nZVI} / \mathrm{BC}(T=$ $25^{\circ} \mathrm{C}, \mathrm{pH}=4.0, \mathrm{nZVI} / \mathrm{BC}$ dosage $=1.5 \mathrm{~g} \mathrm{~L}^{-1}$ ).

Table 3 The adsorption isotherm parameters of $\mathrm{Cr}(\mathrm{VI})$ on the $\mathrm{nZVI} / \mathrm{BC}$

\begin{tabular}{llccc}
\hline \multirow{2}{*}{ Model } & & \multicolumn{2}{c}{ Temperature $\left({ }^{\circ} \mathrm{C}\right)$} \\
\cline { 3 - 5 } & Parameters & 25 & 30 & 35 \\
\hline \multirow{2}{*}{ Langmuir } & $b\left(\mathrm{~g} \mathrm{~L}^{-1}\right)$ & 0.125 & 0.141 & 0.155 \\
& $Q_{\mathrm{m}}\left(\mathrm{mg} \mathrm{g}^{-1}\right)$ & 35.30 & 41.00 & 46.73 \\
& $R^{2}$ & 0.988 & 0.990 & 0.994 \\
Freundlich & $K_{\mathrm{F}}\left(\mathrm{L} \mathrm{mg}^{-1}\right)$ & 11.09 & 15.74 & 19.19 \\
& $1 / n$ & 0.226 & 0.191 & 0.170 \\
& $R^{2}$ & 0.984 & 0.986 & 0.988
\end{tabular}

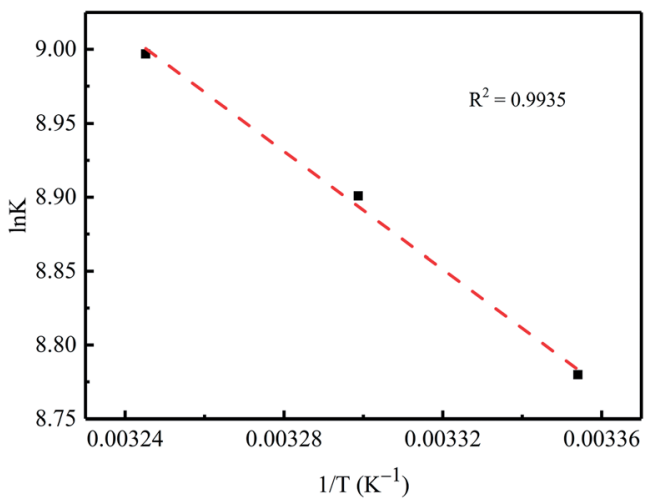

Fig. 10 OVariation of equilibrium constant $K$ as a function of temperature $(1 / T)$.
Table 4 Thermodynamic parameters of $\mathrm{Cr}(\mathrm{VI})$ adsorption on the $\mathrm{nZVI} /$ $\mathrm{BC}$

\begin{tabular}{lllll}
\hline$T / K$ & $\ln K$ & $\begin{array}{l}\Delta G^{\circ} \\
\left.(\mathrm{kJ} \mathrm{mol})^{-1}\right)\end{array}$ & $\begin{array}{l}\Delta H^{\circ} \\
\left(\mathrm{kJ} \mathrm{mol}^{-1}\right)\end{array}$ & $\begin{array}{l}\Delta S^{\circ} \\
\left(\mathrm{J} \mathrm{mol}{ }^{-1} \mathrm{~K}^{-1}\right)\end{array}$ \\
\hline 298.15 & 8.780 & -21.76 & 16.59 & 128.67 \\
303.15 & 8.901 & -22.44 & & \\
308.15 & 8.997 & -23.05 & &
\end{tabular}

of $\mathrm{FeOOH}, \mathrm{Fe}_{2} \mathrm{O}_{3}$ or $\mathrm{Fe}_{3} \mathrm{O}_{4}$, which were not clearly observed in the nZVI/BC before contacting with the $\mathrm{Cr}(\mathrm{vI})$ solution. In addition, the diffraction peaks at $36.2^{\circ}$ and $55.5^{\circ}$ could be derived from the (110) and (116) characteristic diffraction peaks of $\mathrm{Cr}_{2} \mathrm{O}_{3}$ (JCPDS no. 38-1479), respectively. ${ }^{39,40}$ As a result, it can be deduced from Fig. 8 that $\mathrm{Cr}(\mathrm{VI})$ could be reduced to $\mathrm{Cr}(\mathrm{III})$ in $\mathrm{Cr}_{2} \mathrm{O}_{3}(\mathrm{~s})$ or the $\mathrm{Cr}(\mathrm{OH})_{3}(\mathrm{~s})$ form and $\mathrm{Fe}^{0}$ could be oxidized to $\mathrm{FeOOH}, \mathrm{Fe}_{2} \mathrm{O}_{3}$, and $\mathrm{Fe}_{3} \mathrm{O}_{4} \cdot{ }^{39,41,42}$

To further demonstrate the composition of the product, XPS analysis was performed. Compared with the freshly prepared $\mathrm{nZVI} / \mathrm{BC}$, after treatment with the $\mathrm{Cr}(\mathrm{VI})$ solution two new peaks appeared in curve i of Fig. 12a. As shown in Fig. 12b, there are two peaks at $586.8 \mathrm{eV}\left(\mathrm{Cr} 2 \mathrm{p}_{1 / 2}\right)$ and $577.3 \mathrm{eV}\left(\mathrm{Cr} 2 \mathrm{p}_{3 / 2}\right)$ after the reaction, indicating that $\mathrm{Cr}(\mathrm{III})$ compounds such as $\mathrm{CrOOH}$, $\mathrm{Cr}(\mathrm{OH})_{3}$, and $\mathrm{Cr}_{2} \mathrm{O}_{3}$ were the main chromium species on the surface. ${ }^{33,43,44}$ Fig. $12 \mathrm{c}$ demonstrates the detailed curve-fitting spectra of the Fe 2p. The Fe 2p peaks at $710.4 \mathrm{eV}$ and $711.8 \mathrm{eV}$ can be assigned to $\mathrm{Fe} 2 \mathrm{p}_{3 / 2}$ for $\mathrm{Fe}_{2} \mathrm{O}_{3}$ and/or FeOOH and $\mathrm{Fe}_{3} \mathrm{O}_{4}$. The peak at a binding energy of $725.0 \mathrm{eV}$ indicated the existence of both $\mathrm{Fe}$ (II) and $\mathrm{Fe}$ (III) $\left(\mathrm{Fe}_{3} \mathrm{O}_{4}\right.$ and/or $\left.\mathrm{FeOOH}\right) \cdot{ }^{43-46}$ In addition, the peaks at $714.6,718.9$, and $733.4 \mathrm{eV}$ can be ascribed to the satellite peaks of the $\mathrm{Fe}$ (II) and $\mathrm{Fe}(\mathrm{III})$ compounds. ${ }^{47}$ The XRD and XPS results demonstrate that $\mathrm{Cr}(\mathrm{VI})$ could be reduced to $\mathrm{Cr}(\mathrm{III})$, while and nZVI could be oxidized to Fe(II) and Fe(III) compounds during the $\operatorname{Cr}(\mathrm{vI})$ removal.

\subsection{Prospects and challenges}

Nano zero valent iron (nZVI) has been shown to be an inexpensive and environmentally friendly material that can be applied to remediate many environmental contaminants (e.g. organic and heavy metal pollution). The pyrolysis of inexpensive and renewable biomass and iron salt should potentially be a greener and more sustainable pathway to produce the nZVI/BC sorbent for environmental remediation. ${ }^{21}$ Although the batch experiment results have shown that the nZVI/BC exhibited an excellent $\mathrm{Cr}(\mathrm{vI})$ adsorption capacity, batch processing is generally not appropriate for industrial applications. The optimal adsorption process on a large scale should be dynamic (continuous flow mode) adsorption. In this study, the powdered nZVI/BC could present appreciable problems for column adsorption, so the next step will be to focus on studying the preparation of the granular sorbent and to study the adsorption capacity for pollution in continuous flow mode. Another challenge should be to reduce the energy consumption for the nZVI/BC synthesis process under higher temperature. Pyrolysis under a reducing atmosphere (e.g. $\mathrm{CO}$ or $\mathrm{H}_{2}$ ) should be a potential pathway. 
Table 5 Comparison of the maximum $\mathrm{Cr}(\mathrm{VI})$ adsorption capacity among $\mathrm{nZVI}$ and other related adsorbents

\begin{tabular}{lllll}
\hline Sorbent & Preparation method & $\begin{array}{l}\text { Initial } \\
\mathrm{pH}\end{array}$ & $\begin{array}{l}\text { Adsorption capacity } \\
\left(\mathrm{mg} \mathrm{g}^{-1}\right)\end{array}$ \\
\hline nZVI & Liquid reduction & 3.0 & 17.61 & 38 \\
nZVI/BC & Liquid reduction & 4.0 & 40.00 & 17 \\
nZVI/zeolite & Liquid reduction & 7.0 & 2.49 & 37 \\
nZVI/BC & One-step pyrolysis & 4.0 & 35.30 & This work
\end{tabular}

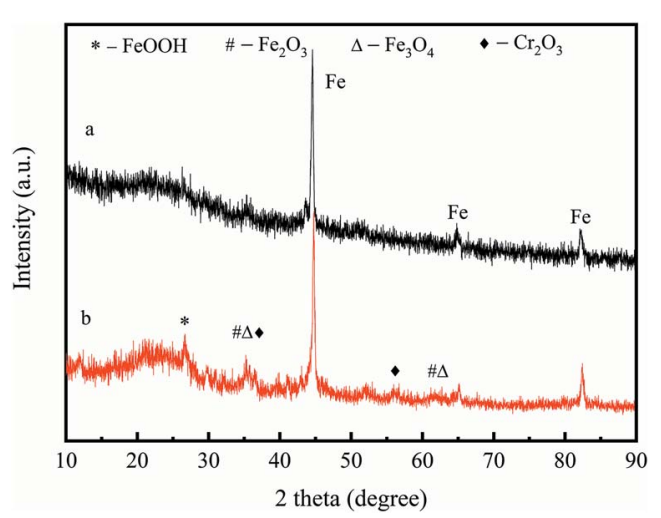

Fig. 11 XRD diffraction patterns for the $\mathrm{nZVI/BC}$ before (a) and after (b) treatment with $\mathrm{Cr}(\mathrm{vI})$ solution.
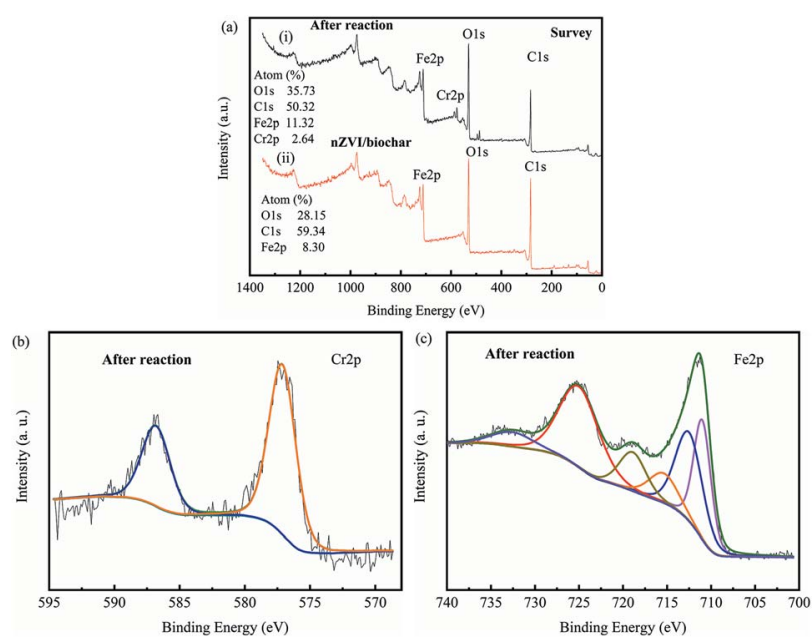

Fig. 12 XPS survey (a) for (i) nZVI/BC, (ii) after reaction with $\mathrm{Cr}(\mathrm{VI})$ solution and high-resolution XPS spectra for $\mathrm{Cr} 2 \mathrm{p}(\mathrm{b}), \mathrm{Fe} 2 \mathrm{p}$ (c) in $n Z V I / B C$ after reaction with $\mathrm{Cr}(\mathrm{VI})$ solution.

\section{Conclusions}

In this study, nZVI/BC was successfully synthesized by a onestep pyrolysis of $\mathrm{Fe}(\mathrm{III})$-impregnated corn stover under a nitrogen atmosphere. The most probable pore size for nZVI/ BC was about $50 \mathrm{~nm}$. TEM imaging showed that the nZVI were well-scattered in the biochar. Then, the as-prepared nZVI/ $\mathrm{BC}$ was applied in the $\mathrm{Cr}(\mathrm{vI})$ removal from aqueous solutions. It was found that the removal efficiency for $\mathrm{Cr}(\mathrm{vI})$ decreased with the increase in the initial $\mathrm{pH}$ value of the $\mathrm{Cr}(\mathrm{vI})$ solution in the range of 4.0-10.0. The $\mathrm{Cr}(\mathrm{VI})$ concentration decreased rapidly from 10 to $0.046 \mathrm{mg} \mathrm{L}^{-1}$ in the first few minutes and then reached equilibrium (near 0 ) after $30 \mathrm{~min}$. The $\mathrm{Cr}$ (vI) adsorption kinetics effectively followed a pseudo-second-order expression and the adsorption isotherm data were well fitted by the Langmuir model. The results of the XRD and XPS indicated that the adsorption mechanism included the $\mathrm{Cr}(\mathrm{vI})$ reduction accompanied by nZVI oxidation. The thermodynamic analysis showed that the $\mathrm{Cr}(\mathrm{vI})$ adsorption process by $\mathrm{nZVI} / \mathrm{BC}$ is spontaneous and a high temperature is more favourable. These results demonstrate that nZVI/BC synthesized by a one-step carbothermal method can behave as a potential adsorbent for $\mathrm{Cr}(\mathrm{vI})$ containing water treatment.

\section{Conflicts of interest}

The authors declare no conflicts of interest.

\section{Acknowledgements}

We thank the National Key R\&D Program of China (No. 2017YFD0800301), Science and Technology Program of Shenyang (No. 18-013-0-28), General Project of Liaoning Provincial Department of Education (No. LQ2017012), Natural Science Foundation of Liaoning Province (No. 20170540727), and the opening fund of Key Laboratory of Original Agro-Environmental Pollution Prevention and Control, Ministry of Agriculture/ Tianjin Key Laboratory of Agro-environment and Safe-product (No. 18nybcdhj-7) for the financial support.

\section{References}

1 B. Dhal, H. N. Thatoi, N. N. Das and B. D. Pandey, J. Hazard. Mater., 2013, 250-251, 272.

2 A. Zhitkovich, Chem. Res. Toxicol., 2011, 24, 1617.

3 C. E. Barrera-Díaza, V. Lugo-Lugo and B. Bilyeu, J. Hazard. Mater., 2012, 223-224, 1.

4 T. K. Voa, H. K. Parkb, C. W. Namb, S. D. Kimb and J. Kima, J. Ind. Eng. Chem., 2018, 60, 485.

5 G. Qu, L. Kou, T. Wang, D. Liang and S. Hu, J. Environ. Manage., 2017, 201, 378.

6 A. Nam, U. S. Choi, S. T. Yun, J. W. Choi, J. A. Park and S. H. Lee, J. Ind. Eng. Chem., 2018, 66, 187.

7 Y. Zou, X. Wang, A. Khan, P. Wang, Y. Liu, A. Alsaedi, T. Hayat and X. Wang, Environ. Sci. Technol., 2016, 50, 7290.

8 F. Ogataa, E. Uetaa and N. Kawasakia, J. Ind. Eng. Chem., 2018, 59, 56. 
9 W. Zhang, J. Nanopart. Res., 2003, 5, 323.

10 Y. Fang, J. Wen, G. Zeng, M. Shen, W. Cao, J. Gong and Y. Zhang, Environ. Sci. Pollut. Res., 2018, 25, 6175.

11 Y. Li, Z. Jin, T. Li and Z. Xiu, Sci. Total Environ., 2012, 421422, 260-266.

12 Y. Y. Zhang, H. Jiang, Y. Zhang and J. F. Xie, Chem. Eng. J., 2013, 229, 412.

13 F. Fu, J. Ma, L. Xie, B. Tang, W. Han and S. Lin, J. Environ. Manage., 2013, 128, 822.

14 H. Zhu, Y. Jia, X. Wu and H. Wang, J. Hazard. Mater., 2009, $172,1591$.

15 H. Dong, J. Deng, Y. Xie, C. Zhang, Z. Jiang, Y. Cheng, K. Hou and G. Zeng, J. Hazard. Mater., 2017, 332, 79.

$16 \mathrm{~W}$. Gwenzi, N. Chaukura, C. Noubactep and F. N. D. Mukome, J. Environ. Manage., 2017, 197, 732.

17 L. Qian, W. Zhang, J. Yan, L. Han, Y. Chen, D. Ouyang and M. Chen, Environ. Pollut., 2017, 223, 153.

18 Y. F. Su, Y. L. Cheng and Y. H. Shih, J. Environ. Manage., 2013, 129, 361.

19 S. H. Ho, S. Zhu and J. S. Chang, Bioresour. Technol., 2017, 246, 123.

20 P. Wang, L. Tang, X. Wei, G. Zeng, Y. Zhou, Y. Deng, J. Wang, J. Wang, Z. Xie and W. Fang, Appl. Surf. Sci., 2017, 392, 391.

21 M. Lawrinenko, D. A. Laird and J. H. van Leeuwen, ACS Sustainable Chem. Eng., 2017, 5, 767.

22 R. Li, J. J. Wang, L. A. Gaston, B. Zhou, M. Li, R. Xiao, Q. Wang, Z. Zhang, W. Liang, H. Huang and X. Zhang, Carbon, 2018, 129, 674.

23 R. He, Z. Peng, H. Lyu, H. Huang, Q. Nan and J. Tang, Sci. Total Environ., 2018, 612, 1177.

24 H. Liu, M. Li, T. Chen, C. Chen, N. S. Alharbi, T. Hayat, D. Chen, Q. Zhang and Y. Sun, Environ. Sci. Technol., 2017, 51, 9227.

25 F. Magalhães, M. C. Pereira, J. D. Fabris, S. E. C. Bottrel, M. T. C. Sansiviero, A. Amaya, N. Tancredi and R. M. Lago, J. Hazard. Mater., 2009, 165, 1016.

26 S. Wang, Y. Zhou, B. Gao, X. Wang, X. Yin, K. Feng and J. Wang, Chemosphere, 2017, 186, 495.
27 S. Lagergren, K. Sven. Vetenskapsakad. Handl., 1898, 24, 1.

28 Y. S. Ho and G. McKay, Process Saf. Environ. Prot., 1998, 76, 332.

29 H. A. Toylor and N. Thon, J. Am. Chem. Soc., 1952, 74, 4169.

30 W. J. Jr Weber and J. C. Morris, J. Sanit. Eng. Div., Am. Soc. Civ. Eng., 1963, 89, 31.

31 I. Langmuir, J. Am. Chem. Soc., 1918, 40, 1361.

32 H. M. F. Freundlich, Z. Phys. Chem., 1906, 57, 385.

33 H. Gu, H. Lou, D. Ling, B. Xiang and Z. Guo, RSC Adv., 2016, 6, 110134.

34 H. T. Fan, X. Fan, J. Li, M. Guo, D. Zhang, F. Yan and T. Sun, Ind. Eng. Chem. Res., 2012, 51, 5216.

35 H. Yao, Q. Ding, H. Zhou, Z. Zhao, G. Liu and G. Wang, RSC $A d v .$, 2016, 6, 27039.

36 C. H. Xu, L. J. Zhu, X. H. Wang, S. Lin and Y. M. Chen, Water, Air, Soil Pollut., 2014, 225, 1845.

37 H. Dang, Y. Zhang and P. Du, Water Sci. Technol., 2014, 78, 1398.

38 S. Zhou, Y. Li, J. Chen, Z. Liu, Z. Wang and P. Na, RSC Adv., 2014, 92, 50699.

39 H. Dong, Y. Zeng, G. Zeng, D. Huang, J. Liang, F. Zhao, Q. He, Y. Xie and Y. Wu, Sep. Purif. Technol., 2016, 165, 86.

40 R. Fu, Y. Yang, Z. Xu, X. Zhang, X. Guo and D. Bi, Chemosphere, 2015, 138, 726.

41 Y. Li, W. Cheng, G. Sheng, J. Li, H. Dong, Y. Chen and L. Zhu, Appl. Catal., B, 2015, 174-175, 329.

42 J. Shang, M. Zong, Y. Yu, X. Kong, Q. Du and Q. Liao, J. Environ. Manage., 2017, 197, 331.

43 M. S. H. Mak, I. M. C. Lo and T. Liu, Water Res., 2011, 45, 6575.

44 P. Yang, D. Guo, Z. Chen, B. Cui, B. Xiao, S. Liu and M. Hu, J. Dispersion Sci. Technol., 2017, 38, 1665.

45 J. H. Kim, J. H. Kim, V. Bokare, E. J. Kim, Y. Y. Chang and Y. S. Chang, J. Nanopart. Res., 2012, 14, 1010.

46 I. H. Yoon, S. Bang, K. W. Kim, M. G. Kim, S. Y. Park and W. K. Choi, Environ. Sci. Pollut. Res., 2016, 23, 1081.

47 X. Xia, L. Ling and W. X. Zhang, Chemosphere, 2017, 168, 1597. 